УДК 37: 371.487

\title{
КРИТЕРІЇ ХРОНОЛОГІЇ ІСТОРІЇ ПСИХОСОМАТИЧНИХ СИСТЕМ
}

\section{Олена Твердохліб ${ }^{1}$}

${ }^{1}$ Національний технічний університет України «Київський політехнічний інститут імені Ігоря Сікорського», м. Київ, Україна, velleo2208@gmail.com

https://doi.org/10.29038/2220-7481-2018-04-10-13

\begin{abstract}
Анотації
Aктуальність. У попередніх дослідженнях установлено, що для кваліфікації систем і вправ комплексної регуляції загального стану організму людини засобами тілесної й психічної активності оптимальними є терміни «психосоматичні системи» та «психосоматичні вправи», критерії хронології історії яких $є$ малодослідженою ланкою фізичної культури. Постановка проблеми. Виходячи з того, що психосоматичні системи є складовою частиною загальнолюдської культури, припущено, що хронологія історичного розвитку психосоматичних систем збігається з періодизацією історії людства, культури, фізичної культури. Установлено, що періодизація історії фізичної культури людства грунтується на геологічних, морфологічних, соціально-економічних, генетичних, археологічних та інших принципах, які неоднозначно визначають ії і потребують удосконалення. Мета дослідження - визначити оптимальні критерії хронології історії психосоматичних систем. Метод $u$ дослідження - історичний і логіко-теоретичний аналіз джерел інформації. Результати дослідження. Установлено, що принципи періодизації як загальної історії людства, так і її складників, зокрема фізичної культури, грунтуються на низці критеріїв, таких як поступова морфологічна еволюція людства, зміни в характері знарядь праці, види суспільно-економічних відносин, наявність писемності, які мають численні недоліки. Виявлено базовий критерій загальної хронології історії фізичної культури. Висновки. Оптимальним базовим критерієм хронології історії психосоматичних систем і фізичної культури є термін часу відносно межі, що визначає два періоди: I до нашої ери (із ... до кінця 1 ст. до н. е.); II період - нашої ери (із початку 1 ст. н. е. до сьогодні). Плануються подальші дослідження характеристик давніх психосоматичних систем різних культур.
\end{abstract}

Ключові слова: критерії хронології, історія фізичної культури, психосоматичні системи.

Елена Твердохлеб. Критерии хронологии истории психосоматических систем. Актуальность. В предыдущих исследованиях установлено, что для квалификации систем и упражнений комплексной регуляции общего состояния организма человека средствами телесной и психической активности оптимальными являются термины «психосоматические системы» и «психосоматические упражнения», критерии хронологии истории которых являются малоисследованным звеном физической культуры. Постановка проблемы. Исходя из того, что психосоматические системы является составной общечеловеческой культуры, предполагается, что хронология исторического развития психосоматических систем совпадает с периодизацией истории человечества, культуры, физической культуры. Установлено, что периодизация истории физической культуры человечества базируется на геологических, морфологических, социально-экономических, генетических, археологических и других принципах, которые определяют ее неоднозначно и требуют совершенствования. Цель исследования - определить оптимальные критерии хронологии истории психосоматических систем. Методы исследования - исторический и логико-теоретический анализ источников информации. Результаты исследования. Установлено, что принципы периодизации как общей истории человечества, так и ее составляющих, в частности физической культуры, основанные на ряде критериев, таких как постепенная морфологическая эволюция человечества, изменения в характере орудий труда, виды общественно-экономических отношений, наличие письменности, которые имеют ряд недостатков. Обнаружено базовый критерий общей хронологии истории физической культуры. Выводы. оптимальным базовым критерием хронологии истории психосоматических систем и физической культуры является период времени относительно границы, определяет два периода: I - до нашей эры (с ... до конца 1 в. до н. э.); II период - нашей эры (до началу 1 в. н. э. до современности). Планируются дальнейшие исследования характеристик древних психосоматических систем различных культур.

Ключевые слова: критерии хронологии, история физической культуры, психосоматические системы.

Olena Tverdokhlib. Criteria of Chronology of the Psychosomatic Systems History. Topicality. In previous studies it has been established that for the qualification of systems and exercises of complex regulation of the human body's general condition by means of physical and psychic activity, the «psychosomatic systems» and «psychosomatic exercises» terms are optimal, also the criteria of the chronology history of which are a poorly researched link of physical culture.

Formulating the research problem. Proceeding from the fact that psychosomatic systems are an integral part of human culture, it was assumed that the chronology of the historical development of psychosomatic systems coincides

10 ISSN 2410-2156 (Online), ISSN 2220-7481 (Print)

() 2018 Східносвропейський національний університет імені Лесі Українки. Ця стаття відкритого доступу на умовах CC BY-NC 4.0 
with the periodization of mankind`s history, culture, and physical culture. It has been established that the humanity physical culture history periodization is based on geological, morphological, socio-economic, genetic, archeological and other principles that define it unambiguously and need improvement.

The purpose of the research is to determine the optimal criteria for the history chronology of psychosomatic systems. The methods of the research are historical, logical, and theoretical analysis of information sources. The results of the research. It is established that periodization`s principles, as the general history of mankind and its components, in particular, physical culture, are based on a number of criteria such as humanity gradual morphological evolution, tool types changes, forms of socio-economic relations, availability of writing script, having a number of disadvantages. The basic criterion of the general physical education history chronology was revealed. Conclusions. The optimal basic criterion for the history chronology of psychosomatic systems and physical culture is the time period relative to the limit, which determines two periods: the I period - to our era (from ... to the end of the 1st century BC); the II period is our era (from the beginning of the 1st century AD to the present). Further research on the characteristics of ancient psychosomatic systems of different cultures will be planning.

Key words: criteria of chronology, history of physical culture, psychosomatic systems.

Вступ. У попередніх дослідженнях установлено, що для кваліфікації систем і вправ комплексної регуляції загального стану організму людини засобами тілесної й психічної активності оптимальними є терміни «психосоматичні системи» та «психосоматичні вправи», які забезпечують термінологічну узгодженість між медичною, педагогічною галузями й фізичною культурою та спортом [1].

Історію культових систем досліджували J. Bowker, M. Eliade, О. Мень, А. Фанталов. На їхню думку ці системи виникли й еволюціонували разом із людством. Історію фізичної культури досліджували [2-6], I. К. Попеску, С. М. Філь, О. М. Худолій, Г. В Малка та ін., історію національних систем психофізичного виховання України - А. Цьось, С. Приступа, В. Левків, В. Старков, Н. Деделюк й ін. Загальна історія розвитку психосоматичних систем, що є складовою частиною загальнолюдської історії, малодосліджена ланка фізичної культури (О. Вацеба). Виходячи з того, що психосоматичні системи $є$ компонентом загальнолюдської культури, ми припускаємо, що хронологія історичного розвитку психосоматичних систем збігається з періодизацією історії людства, культури, фізичної культури.

Мета дослідження - визначити оптимальні критерії хронології історії психосоматичних систем.

Методи дослідження - історичний і логіко-теоретичний аналіз джерел інформації.

Результати дослідження. Серед загалу критеріїв хронології загальної історії й культури вагоме місце посідає критерій часу виникнення писемності, відповідно до якого історію поділяють на два періоди - доісторичний та історичний. На нашу думку, стосовно психосоматичних систем цей хронологічний критерій не є оптимальним, оскільки час виникнення писемності не обмежений і нині існують народи, котрі не мають писемності.

Нараховується понад десяток наукових теорій, що грунтуються на морфологічних принципах антропогенезу (С. В. Смирнов). Найбільш поширена та, що сформувалась у середині ХІХ ст., відповідно до якої еволюція людства почалась у часовому періоді 4-2,5 млн до 700-100 тис. років тому та мала п'ять етапів, кожному 3 яких відповідав певний тип людиноподібних приматів: австралопітек (4-1 млн років тому); пітекантроп, або яванська людина (800-500 тис. років тому); синантроп, або пекінська людина (460-230 тис. років тому); неандерталець (200-35 тис. років тому); кроманьйонець, або Homo sapiens (40 тис. років тому). За даними сучасних досліджень, теорія антропогенезу має багато невідповідностей морфологічного, зоогеографічного, геологічного, генетичного й загальнобіологічного порядку: сучасні представники різних рас походять від єдиного африканського генетичного кореня [7]; південноафриканські австралопітеки, гомініди типу яванської й пекінської людини та неандертальця не є прямими предками людини розумної; хронологічні межі початку антропогенезу сягають 2800 млн років тому, а територіальні межі розширюються на всі населені континенти [8].

За критеріями, які грунтуються на змінах характеру знарядь праці й фізичного типу людей, історія людства поділяється на етапи: палеоліт, або кам’яний вік (3-2 млн - 10 тис. до н. е.), що розмежовується на ранній палеоліт (3-2 млн - 35 тис. до н. е.), який ділиться на дошельську (3 млн 500 тис. до н. е.), шельську (500-300 тис. до н. е.), ашельську (300-150 тис. до н. е.) і мустьєрську (150- 40-35 тис. до н. е.) епохи; пізній палеоліт (40-35 - 10 тис. до н. е.), який ділиться на епохи, оріньяк (40-30 тис. до н. е.), солютре (35-25 тис. до н. е.) і мадлен (25-12 тис. до н. е.); мезоліт (10-5 тис. до н. е.), неоліт, або новий кам'яний вік (8-3 тис. до н. е.), енеоліт, або мідяний вік (4-3 тис. до н. е.), бронзовий вік (3-1 тис. до н. е.), залізний вік (із 1 тис. до н. е.) [9]. Сучасні дослідження спростовують, вищезазначені дати початку трудової діяльності людини, датуючи ії 2800 млн років тому [8], а також межі етапів історії людства (деякі його представники досі користуються кам'яними знаряддями праці). 
За марксистською періодизацією за формою власності на засоби праці історія людства поділяється на первіснообщинний лад (спільне володіння засобами праці), рабовласницький (сформувався на межі 4-3 тис. до н. е.), феодальний (5-9 ст.), капіталістичний (14-15 ст.), соціалістичний тощо. Періодизація, що керується виробничою діяльністю, яка запропонована Генрі Морганом у 1877 р., ділить первісну епоху на стадії полювання, землеробства й скотарства, періоди дикунства, варварства та цивілізації. Виходячи з того, що в сучасності й досі співіснують різні суспільні устрої та такі види діяльності, як полювання, землеробство й скотарство, на нашу думку, критерії форм власності на засоби праці й виробничої діяльності також не задовільні в загальній хронології історії фізичної культури. Фахівці [1-6 та ін.] розподіляють історію фізичної культури на періоди на базі трьох принципів: теорії еволюції людства Ч. Дарвіна, характеру знарядь праці й видів суспільно-економічних відносин.

Форми фізичної культури за [3] визначаються видом класових суспільно-економічних відносин, а предмет історії фізичної культури - це загальні закономірності виникнення й розвитку фізичної культури та спорту на різних етапах існування людського суспільства, засоби, форми та методи, ідеї, теорії й системи фізичної культури, виховання, навчання, підготовки до праці й воєнної діяльності. У первіснообщинному суспільстві свідомість і духовний світ давньої людини, на думку вченого, відігравали важливу роль. Перед полюванням або воєнними діями виконувалися певні магічні дії й рухи. Практикували релігійно-культові обряди, ігри, ініціації (при переході з однієї вікової групи до іншої або прийомі до членів общини чи культу), танці в супроводі музики та хорового співу в народів півночі (4-2 тис. до н. е.), Греції й Риму (3-2 тис. до н. е.), скіфи (7-1 ст. до н. е.). У середньовіччі в Індії практикували йогу, у Китаї - ушу, у Японії - інститут лицарства самураїв бусідо, сумо, джіуджіцу, карате, кендо. В Америці (12-15 ст.) - релігійні церемонії, ритуальні танці, акробатичні вправи й змагання, в Африці - танці під звуки тамтама.

Л. Кун уважає, що фізична культура як специфічна сфера суспільної діяльності сформувалась у ...80 000-800 pр. до н. е., а іiі зображення в образотворчому мистецтві почалося з культових подань Шумеру (новорічні ритуальні змагання на честь бога Мардука; 4 тис. до н. е.) та Давнього Єгипту (рельєф фараона Джосера, котрий біжить; 3 тис. до н. е.), хоча наводить більш ранні культові зображення Європи з печер Труа Фрер 15000 р. до н. е. і Пеш-Мерль 20-15000 рр. до н. е., на бронзових посудинах із Куфферна 6 тис. до н. е. і Васа 5 тис. до н. е. Він подає історію фізичної культури з 150000 року до н. е. та відзначає, що у 40000 р. до н. е. практикувалися магічні дії. В епоху мезоліту й неоліту (8000-3000 pp. до н. е.) на перший план висуваються танці та медитації типу йоги, які грунтувалися на віруваннях, пов'язаних із родючістю, а центр ваги церемоній посвячення зосередився на формах рухів, характерних для бойової підготовки. Одноборства перед боєм слугували пробою сил або передбачення, символізували непереможність і силу героїв спільноти. Таку саму мету мав ритуал виклику на бій суперника. У ході розвитку патріархально-родового суспільства загального характеру набула підготовка до церемоній посвячення у воїни, з'явилися постійні ритуальні центри, а церемонії посвячення та вибору вождя племені проводили родові спільноти. В епоху переходу від первіснообщинного суспільства до класового виник естетичний ідеал героя, який володів надприродними тілесними й духовними силами, вів боротьбу з потойбічними силами й здобував для людства таємниці цих сил (Гільгамеш - у вавилонян, Осіріс - у єгиптян, Великий Ю - у китайців, Геракл - у греків, Зігфрид - у германців, Кешар - у тибетців, Рустем - у персів). У період 4 тис. до н. е. -476 р. н. е. зміст фізичного виховання відрізнявся щільним переплетенням мотивів рухів із магією, містикою, релігійно-культовими, лікувальними, виховними, військовими й прикладними функціями. Із 3 тис. до н. е. в Індії культивувались оздоровчі вправи йоги, що грунтувалися на традиціях раціональної магії, які еволюціонували в містифіковану систему рухів, найвищі ступені яких були доступні лише для посвячених. У 2 ст. до н. е. вправи йоги використовували в бальнеологічній терапії, а вправи розумової концентрації - у професійно-прикладній підготовці лікарів, військових, діячів мистецтв. У 3 тис. до н. е. у Китаї сформувалася система кунг фу, що включала лікувальні й бойові вправи, гімнастику, масаж, танці, пантоміму. Починаючи 36 ст. до н. е., у даоських школах практикували ней кунг - пасивні рухи в положенні сидячи по-турецьки, тао цзинь - активні рухи разом із дихальними лікувальними вправами, які позбавляли від хвороб і слабкості, розвивали силу й міць, кун цзи - лікувальну гімнастику, яка грунтувалася на розтягувальних і розслаблювальних вправах та принципах урівноваження пари протилежностей, що розроблена даоським лікарем Хуа Те на основі спостережень за тваринами й птахами. У 2 тис. до н. е. на о. Крит культивувалися публічні церемонії, ініціації, ритуальні танці, акробатичні вправи та стрибки через бика. Історію фізичної культури автором подано фрагментарно: 4 тис. до н. е. -476 р. н. е. - Месопотамія, Сгипет, Індія, Китай; 2 тис. до н. е. -6 ст. н. е. - Антична 
Греція; 8 ст. до н. е. - 476 р. н. е. - Давній Рим; 5-18 ст. - Свропа; 3-17 ст. - Індія, Китай, Японія, Америка (ацтеки, майя, інки); 18-20 ст. - всесвітня історія нового часу; із 1917 р. - новітня епоха.

Як бачимо, хронології загальної історії фізичної культури за такими критеріями, як поступова морфологічна еволюція людства, зміни в характері знарядь праці, види суспільно-економічних відносин, наявність писемності, не охоплюють загалом психосоматичних систем. За поданнями істориків фізичної культури їм відведено місце в часовому проміжку з доісторичного періоду до середньовіччя, а в наступні часи вони згадуються у зв'язку з «примітивними» племенами сучасності. Магічні рухи й ритуали відносять до «первісних часів», хоча вони й досі практикуються. Як у давнину, так і в сьогоденні, практикуються техніки психосоматичних систем релігійно-культових, йоги, цигуну, східних бойових мистецтв та ін.

Висновки та перспективи подальших досліджень. У результаті дослідження встановлено, що хронологія, як загальної історії людства, так ії̈ складової частини фізичної культури, грунтується на низці критеріїв, таких як поступова морфологічна еволюція людства, зміни в характері знарядь праці, види суспільно-економічних відносин, наявність писемності, що недосконало визначають ії. Оптимальним базовим критерієм хронології історії психосоматичних систем і фізичної культури є термін часу, що визначає два періоди: I - до нашої ери (... до кінця 1 ст. до н. е.); II період - нашої ери (із початку 1 ст. н. е. до сьогодення). Плануються подальші дослідження характеристик давніх психосоматичних систем різних культур.

\section{Джерела та література}

1. Твердохліб, О. Дослідження понятійного поля психосоматичних вправ в галузі фізичного вихованя $\mathrm{i}$ спорту. Теорія і методика фіз. виховання і спорту. 2007. № 2. С. 35-39.

2. Пономарев Н. И. Возникновение и первоначальное развитие физического воспитания. Москва: Физкультура и спорт, 1970. 248 с.

3. История физической культуры и спорта: учеб. для ин-тов физ. культ./под ред. В. В. Столбова. Москва: Физкультура и спорт, 1983. 359 с.

4. Кун Л. Всеобщая история физической культуры и спорта/под. общ. ред. В. В. Столбова; пер. с венг. И. П. Абоимова. Москва: Радуга, 1982. 398 с.

5. Zeigler F. Historical foundation: social and educational. A history of physical education and sport in the United States and Canada (Selected topics). USA: Stipes Publishing Company, 1975. P. 11-27.

6. Цьось А. В. Розвиток фізичного виховання на території України з найдавніших часів до початку XIX ст.: дис. ... д-ра наук з фіз. виховання і спорту. Луцьк, 2005. 427 с.

7. Spencer Wells The Journey of Man:A Genetic Odyssey With a new preface by the author. USA: Princeton University Press, 2017. 240 p.

8. Cremo M. A., Thompson R. L. Forbidden Archeology: The Hidden History of the Human Race. 2nd ed. San Diego: Bhaktivedanta Book Publishing, 1998. 914 p.

9. Новый иллюстрированный энциклопедический словарь/под ред. В. И. Бородулин и др. Москва: Науч. изд-во «Большая Российская энциклопедия», 1999. 911 с.

\section{References}

1. Tverdokhlib, O. (2007). Doslidzhennya ponyatiynoho polya psykhosomatychnykh vprav v haluzi fizychnoho vykhovanya i sportu [Research of the psychosomatic exercises conceptual field in the field of Physical Education and Sports]. Teoriya i metodyka fiz. vykhovannya i sportu, no. 2, 35-39.

2. Ponomarev, N. Y. (1970). Voznyknovenye y pervonachal'noe razvytye fyzycheskoho vospytanyya [The creation and original evolution of physical education]. M.: Fyzkul'tura y sport, 248.

3. Stolbov, V. V. (1983). Ystoryya fyzycheskoy kul'tury y sporta [The history of physical culture and sports ]: ucheb. dlya yn-tov fyz. kul’t. M: Fyzkul'tura y sport, 359.

4. Kun, L. (1982) Vseobshchaya ystoryya fyzycheskoy kul'tury y sporta / Pod. obshch. red. V.V. Stolbova; per. s venh. Y. P. Aboymova. M.: Raduha, 398 s.

5. Zeigler, F. (1975). Historical foundation: social and educational. A history of physical education and sport in the United States and Canada (Selected topics). USA: Stipes Publishing Company. 11-27.

6. Tsos, A. V. Rozvytok fizychnoho vykhovannya na terytoriyi Ukrayiny z naydavnishykh chasiv do pochatku XIX st.: dy. ... dok. nauk $z$ fiz. vykhovannya i sportu. [The development of the phisical education on the territory of Ukraine from the foundations to the end of the 19th century]. Luts'k, 427.

7. Spencer, Wells. (2017). The Journey of Man:A Genetic Odyssey With a new preface by the author. USA: Princeton University Press, 240.

8. Cremo, M. A., Thompson, R. L. (1998). Forbidden Archeology: The Hidden History of the Human Race. 2nd ed. San Diego: Bhaktivedanta Book Publishing, 914.

9. Borodulin, V. I. and others. (1999). Novy yllyustryrovannyy entsyklopedycheskyy slovar' [New Illustrated Encyclopedic Dictionary]. Pod red. V.Y. Borodulyn y dr. M.: Nauch. yzd-vo «Bol'shaya Rossyyskaya entsyklopedyya», 911. 